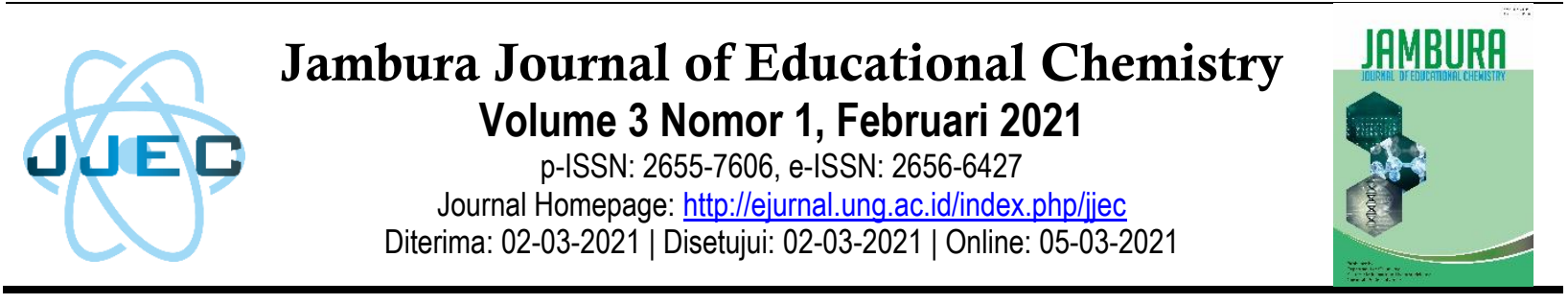

\title{
Pengembangan Media Pembelajaran Tera-Tera untuk Meningkatkan Minat Belajar Siswa pada Materi Larutan Penyangga
}

\author{
Nurpepi Pakuna1, Hendri Iyabu², Suleman Duengo³ \\ Prodi Pendidikan Kimia, Jurusan Kimia, Fakultas MIPA, Universitas Negeri Gorontalo \\ Jl. Prof. Dr. Ing. B. J. Habibie, Moutong, Tilongkabila, Kabupaten Bone Bolango, Gorontalo, \\ Indonesia \\ e-mail: nurpepipakuna803@gmail.com
}

\begin{abstract}
Abstrak
Penelitian ini bertujuan menguji validitas media pembelajaran tera-tera untuk meningkatkan minat belajar siswa pada materi larutan penyangga. Penelitian ini merupakan jenis penelitian pengembangan atau Research and Development (R\&D) dengan model pengembangan ADDIE. Adapun tahap tersebut yaitu: Analysis, Design, Development, Implementation dan Evaluasi. Namun, dalam penelitian ini hanya sampai tahap development. Teknik pengumpulan data pada penelitian ini menggunakan lembar validasi penilaian kelayakan media pembelajaran tera-tera. Kelayakan media tera-tera dinilai oleh 4 orang validator ahli yaitu 3 orang dosen kimia UNG dan 1 orang guru SMA. Hasil validasi pengembangan media pembelajaran tera-tera diperoleh persentase rata-rata 90,00\% dengan kriteria sangat valid untuk digunakan sebagai media pembelajaran. Berdasarkan hasil penelitian yang didapatkan bahwa media pembelajaran tera-tera yang dikembangkan sangat layak digunakan dalam proses pembelajaran materi larutan penyangga.
\end{abstract}

Kata Kunci: Media Pembelajaran, Tera-tera, Minat Belajar, Larutan Penyangga

\section{PENDAHULUAN}

Pendidikan tidak akan lepas dari proses belajar mengajar yang melibatkan interaksi antar guru dan siswa dalam lingkungan sekolah. Di dalam pendidikan, proses belajar mengajar dan proses pembelajaran melibatkan guru sebagai pengajar dan siswa sebagai pelajar. Pembelajaran adalah proses atau kegiatan belajar mengajar dimana guru mata pelajaran mengajarkan materi pelajaran pada siswanya. Salah satu pembelajaran yang diajarkan di sekolah yaitu pembelajaran kimia (Rengen et al., 2017).

Pembelajaran kimia berisi konsep-konsep yang cukup sulit dikuasai oleh siswa, karena menyangkut reaksi-reaksi kimia dan perhitungan, sehingga menyebabkan siswa merasa kesulitan dalam belajar kimia. Pembelajaran yang dikemas secara menarik diharapkan mampu memberikan suasana pembelajaran yang berbeda dan membekas bagi siswa tetapi yang paling utama adalah membantu siswa menguasai materi kimia (Argandi \& Martini, 2013).

Salah satu materi kimia yang sulit dipahami siswa yaitu larutan penyangga. Larutan penyangga merupakan materi yang sulit karena memiliki karakteristik penguasaan konsep dan kemampuan matematis siswa, dimana permasalahan yang terjadi saat pembelajaran yaitu kurangnya penguasaan siswa mengenai suatu konsep dan kurangnya kemampuan matematis siswa, serta kurangnya antusias siswa dan cenderung pasif sehingga menyebabkan prestasi belajar siswa masih rendah (Istiana et al., 2015). Kondisi siswa yang je nuh dalam mengikuti kegiatan pembelajaran dapat disebabkan karena beberapa hal, antara lain minat belajar yang kurang, sistem belajar, dan 
mengajarnya yang tidak menarik yang akhirnya mematahkan minat siswa dalam belajar kimia (Kusumawardani et al., 2015).

Berdasarkan observasi dan wawancara dengan guru kimia kelas XI pada tanggal 28 November 2019, menyebutkan bahwa proses pembelajaran kimia masih menggunakan metode ceramah, dimana pembelajaran masih berpusat pada guru. Akan tetapi dengan metode ini, siswa belum mampu menguasai materi kimia. Siswa juga kurang aktif dalam mengikuti pembelajaran di kelas, misalkan siswa jarang sekali bertanya terkait materi yang belum dikuasai, sehingga siswa masih kesulitan dalam menyelesaikan soal yang menyangkut reaksi kimia dan hitungan kimia karena siswa kurang menguasai soal yang diberikan dan rumus-rumus yang digunakan untuk menyelesaikan soal. Salah satu materi yang belum bisa dikuasai siswa adalah larutan penyangga karena siswa sulit menguasai materi tersebut yang menyangkut reaksi-reaksi kimia dan perhitungan.

Kurangnya keterlibatan siswa pada pembelajaran kimia disebabkan oleh berbagai faktor dari dalam diri siswa maupun dari luar. Salah satu faktor dari dalam diri siswa yang mempengaruhi kesungguhan siswa dalam belajar yaitu minat. Minat menjadi salah satu aspek terpenting dalam mendorong keberhasilan pembelajaran karena akan memunculkan ingatan yang baik bagi siswa. Ketika siswa kehilangan minat dalam pembelajaran maka materi pelajaran tersebut akan mudah untuk dilupakan (Novianty et al., 2018).

Selain itu, faktor dari luar yaitu kreativitas guru dalam mengajar juga tampaknya sangat mempengaruhi keberhasilan suatu pencapaian tujuan pembelajaran. Proses pembelajaran kimia selama ini terlihat kurang menarik, sehingga siswa merasa jenuh dan kurang memiliki minat pada pembelajaran kimia, serta suasana kelas cenderung pasif, sedikit sekali siswa yang bertanya pada guru meskipun materi yang diajarkan belum dikuasai. Dalam pembelajaran seperti ini mereka akan merasakan seolah-olah dipaksa untuk belajar sehingga jiwanya tertekan. Keadaan demikian menimbulkan kebosanan, kejengkelan, sikap masa bodoh, motivasi siswa dan minat dalam pembelajaran menjadi rendah. Hal ini berdampak terhadap ketidaktercapaian tujuan pembelajaran kimia (Ristiyani \& Bahriah, 2016).

Berdasarkan permasalahan tersebut diperlukan peran guru untuk kreatif dalam mengajar dengan menggunakan model atau media pembelajaran yang lebih inovasi. Adapun salah satu inovasi yang dapat dilakukan yaitu dengan penerapan model pembelajaran Team Games Tournament (TGT). Model pembelajaran TGT merupakan salah satu strategi pembelajaran aktif untuk menciptakan suatu situasi sedemikian sehingga keberhasilan kelompok ditentukan oleh keberhasilan anggota dalam kelompok itu sendiri (Rengen et al., 2017).

Salah satu keunggulan dari model pembelajaran TGT menurut (Taniredja et al., 2012) yaitu interaksi belajar siswa dalam kelas menjadi aktif dan tidak membosankan. Menurut Slavin (2005), model pembelajaran TGT terdiri dari 5 aktivitas, diantaranya yaitu : penyajian kelas (class presentation), belajar kelompok (team), permainan (game), pertandingan (tournament), penghargaan kelompok (recognition).

$$
\text { Adanya turnamen menjadikan }
$$

pembelajaran TGT memiliki nilai lebih, karena pembelajaran tersebut menjadikan pembelajaran bersifat menyenangkan sehinggga dapat meningkatkan aktivitas siswa (Heriyanto et al., 2014). Setiap kelompok pada pembelajaran TGT berlomba-lomba untuk mendapatkan skor sebanyak mungkin. Kelompok dengan skor tertinggi pada pembelajaran TGT akan mendapatkan penghargaan. Setiap anggota kelompok mengikuti turnamen yang diadakan, maka setiap siswa turut aktif dalam pembelajaran (Ervianna et al., 2012). Model pembelajaran TGT dalam penerapannya dapat dikembangkan dengan pemanfaatan berbagai media.

Media pembelajaran yang digunakan harus bersifat komunikatif, mudah digunakan dan membangkitkan minat siswa dalam kegiatan pembelajaran. Namun bukan berarti media pembelajaran yang digunakan harus selalu bersifat canggih dan pengadaanya memerlukan dana yang cukup besar (Asra, 2016). Salah satu media pembelajaran yang tidak memerlukaan pendanaan yang besar dan mudah didapatkan serta bersifat menyenangkan dan mendidik yaitu dengan 
menggunakan media Tera-Tera. Tera-tera adalah permainan tradisional yang menembakkan karet gelang kesasaran yang ada pada lidi yang dibentuk sudut $90{ }^{\circ} \mathrm{C}$. Tujuan penggunaan media Tera-Tera dalam proses pembelajaran yaitu sebagai media pembelajaran yang dapat membangkitkan minat siswa dan penguasaan konsep dalam proses pembelajaran. Dengan menggunakan media teratera siswa akan tertarik dan mudah untuk menerima, mengerti, dan menguasai pelajaran yang akan dipelajari.

Berdasarkan identifikasi yang telah diungkapkan, rumusan masalah dalam penelitian ini adalah "Bagaimana validitas media pembelajaran tera-tera untuk meningkatkan minat belajar siswa pada materi larutan penyangga?"

\section{METODE PENELITIAN \\ Jenis Penelitian}

Penelitian ini merupakan penelitian pengembangan (Research and Development) yang bertujuan untuk mengembangkan suatu media pembelajaran pada materi larutan penyangga berbasis permainan tradisional tera-tera. Menurut (Sugiyono, 2019) metode penelitian dan pengembangan atau Research and Development merupakan metode penelitian yang digunakan untuk meneliti sehingga menghasilkan produk baru dan selanjutnya menguji keefektifan produk tersebut.

\section{Lokasi dan Waktu Penelitian}

Penelitian ini akan dilakukan di SMA Negeri 1 Telaga. Penelitian ini dilaksanakan pada Semester Genap.

\section{Prosedur}

Prosedur penelitian ini mengadaptasi model pengembangan ADDIE yang dikembangkan oleh Dick and Carry pada tahun 1996, terdiri dari 5 tahap yaitu Analysis (Analisis), Design (Desain), Development (Pengembangan), Implementation (Implementasi), dan Evaluation (Evaluasi). Untuk penelitian ini yang dilakukan sampai pada tahap pengembangan dikarenakan keadaan yang tidak memungkinkan untuk melakukan tahap implementasi dan evaluasi.

\section{Instrumen dan Teknik Pengumpulan Data}

Jenis instrumen yang dgunakan pada penelitian ini menggunakan lembar validasi.
Lembar validasi yang digunakan pada penelitian ini yaitu untuk mengukur validitas media pembelajaran.

Instrumen lembar validasi media permainan tera-tera, dinilai oleh validator I, validator II, validator III dan validator IV. Pengisian lembar penilaian ini bertujuan untuk melihat persentase kelayakan dari media permainan tera-tera yang telah dikembangkan. Informasi yang diperoleh melalui intrumen ini kemudian digunakan sebagai masukan dalam merevisi media pembelajaran yang telah dikembangkan sehingga dapat menghasilkan produk akhir yang valid.

\section{Teknik Analisis Data}

Analisis kelayakan media permainan teratera bertujuan untuk mengukur kualitas perancangan media permainan tera-tera. Adapun indikator lembar validasi penilaian media pembelajaran berbasis permainan terdiri dari :

a. Perwajahan, aspek yang dinilai pada indikator perwajahan yaitu: kejelasan penggunaan font, jenis, ukuran, dan spasi; tata letak atau lay out; kejelasan ilustrasi dan gambar; kejelasan desain tampil.

b. Kelayakan isi, aspek yang dinilai pada indikator kelayakan isi yaitu: kesesuaian dengan KI, KD; kesesuaian dengan kondisi siswa; jelas dan akurat sesuai dengan kebutuhan siswa; bermanfaat dan dapat menambah wawasan peserta didik; kebenaran substansi materi pembelajaran.

c. Konstruksi, aspek yang dinilai pada indikator konstruksi yaitu: kejelasan tujuan pembelajaran yang ingin dicapai; kejelasan urutan langkahlangkah media permainan tera-tera; memotivasi dan menarik perhatian siswa; interaksi (pemberian stimulus dan respon); kelengkapan informasi

d. Kelayakan bahasa, aspek yang dinilai pada indikator kelayakan bahasa yaitu: keterbacaan; kesesuaian dengan kaidah bahasa indonesia yang baik dan benar; pemanfaatan bahasa secara efektif dan efisien (jelas dan singkat).

Kategori validitas setiap kriteria atau aspek ditetapkan berdasarkan kriteria penilaian yang dikemukakan oleh (Ratumanan, 2003), yaitu: 85\% $100 \%$ (Sangat Valid); 69\% - 84\% (Valid); 53\% 68\% (Cukup Valid); 21\% - 36\% (Tidak Valid). 
Untuk presentasi validitas kelayakan diperoleh dengan rumus:

$$
\%=\frac{\sum \text { skor rata-rata }}{\text { skor maksimum }} \times 100 \%
$$

\section{HASIL DAN PEMBAHASAN}

\section{Tahap Analisis (Analysis)}

Tahap analisis merupakan tahap pertama dalam penelitian dan pengembangan ini, karena hasil analisis inilah yang menjadi pedoman dan tolak ukur dalam penyusunan media pembelajaran. Analisis yang dilakukan meliputi:

\section{a. Analisis Kompetensi Dasar Dan Indikator}

Analisis kompetensi dasar dan indikator dalam rencana pelaksanaan pembelajaran sudah mengacu pada kurikulum 2013. Adapun analisis kompetensi dasar dan indikator merupakan acuan dalam mengembangakan media pembalajaran Tera-tera.

\section{b. Analisis Media}

Analisis media dilakukan sebagai dasar dalam mengembangkan media pembelajaran yakni guru dalam proses pembelajaran jarang bahkan tidak menggunakan media pembelajaran. Salah satu media yang digunakan dalam proses pembelajaran adalah media power poin. Dan guru belum pernah menggunakan media pembelajaran berbasis permainan.

\section{c. Analisis Karakteristik Siswa}

Analisis karakteristk siswa dilakukan untuk melihat karakter siswa yang berhubungan dengan keperluan desain dan pengembangan produk yang dikembangkan. Data yang diperoleh dari hasil analisis karakteristik siswa sebagai berikut: (1) Peserta didik kurang memiliki minat belajar karena proses pembelajaran yang masih berpusat pada guru dalam menyampaikan suatu materi sehingga belum memberikan kesempatan siswa untuk berpartisipasi aktif dalam pembelajaran, (2) Peserta didik lebih senang dalam proses pembelajaran guru menggunakan media pembelajaran. (3) Peserta didik lebih suka pembelajaran yang diselingi dengan permainan.

\section{Tahap Perancangan (Design)}

Tahap kedua yaitu tahap design atau perancangan media pembelajaran Tera-tera, meliputi:

\section{a. Pembuatan Konsep}

Konsep desain produk awal media Tera-tera pada dasarnya sama dengan permainan tera-tera pada umumnnya yaitu terdapat lidi dan karet gelang. Produk Tera-tera terdiri dari 1 buah lidi, 5 buah karet gelang, alat tembak terbuat dari karet gelang telah dikepang, soal latihan dalam LKPD, styrofoam, 1 lembar langkah-langkah permainan tera-tera dan peraturan permainan tera-tera. Konsep tera-tera merupakan penerapan permaianan teratera pada umumnya. Pada permainan ini siswa ditugaskan untuk menembakkan karet gelang menuju target yang ada pada lidi. Media tera-tera menyediakan materi dan soal-soal latihan. Pada setiap soal latihan terdapat skor yang akan didapat siswa apabila mampu menjawab soal dengan benar. Besarnya skor yang didapatkan siswa disesuaikan dengan hasil tembakan karet gelang yang jatuh dan kemampuan menjawab soal dengan benar.

\section{b. Menyusun Rencana Pelaksanaan Pembelajaran (RPP)}

Setelah konsep produk jadi, peneliti menyusun Rencana Pelaksanaan Pembelajaran (RPP) yang berisi materi larutan penyangga yang menggunakan model pembelajaran Time Games Tournament (TGT) dengan bantuan media pembelajaran Tera-tera dalam proses pembelajaran. RPP yang digunakan pada penelitian ini mengacu pada format yang dikeluarkan oleh pemerintah dalam PERMENDIKBUD RI Nomor 22 tahun 2016 yang memuat identitas sekolah, identitas mata pelajaran, kelas/semester, materi pokok, kompetensi inti, kompetensi dasar, indikator, tujuan pembelajaran, materi pembelajaran, metode pembelajaran, media pembelajaran, sumber belajar, langkah-langkah pembelajaran, alokasi waktu, serta penilaian hasil pembelajaran.

\section{c. Menyusun Lembar Kerja Peserta Didik (LKPD)}

Menurut DEPDIKNAS (2008:13), LKPD adalah lembaran berisi tugas yang harus dikerjakan oleh peserta didik dalam proses pembelajaran, berisi petunjuk atau langkah-langkah dalam menyelesaiakan tugas sesuai dengan kompetensi dasar dan indikator. Menurut Prastowo (2011), fungsi LKPD yaitu sebagai bahan ajar yang bisa meminimalkan peran pendidik, namun lebih mengaktifkan peserta didik, memudahkan peserta didik untuk memahami materi yang disampaikan, 
memudahkan pelaksanaan pengajaran kepada peserta didik serta sebagai bahan ajar yang ringkas dan kaya tugas untuk berlatih.

\section{Tahap Pengembangan (Development)}

Tahap ketiga yaitu tahap pengembangan yang meliputi 3 tahap, yaitu:

\section{a. Pembuatan Produk}

Pembuatan produk media pembelajaran tera-tera dibuat dalam bentuk gambar atau sketsa langkah-langkah permainan tera-tera yang disesuaikan dengan tujuan pembelajaran materi larutan penyangga untuk proses pembelajaran. Produk yang dihasilkan dalam bentuk gambar atau sketsa langkah-langkah permainan Tera-tera dengan menggunakan Adobe Photoshop CS4. Peneliti juga membuat peraturan permainan yang digunakan dalam produk media Tera-tera.

\section{b. Validasi Ahli}

Media awal yang telah dibuat selanjutnya divalidasi. Tahap validasi ini bertujuan untuk memperoleh pengakuan kelayakan dan memperoleh masukan perbaikan mengenai media yang dikembangkan. Penilaian terhadap media pembelajaran berdasarkan permainan yang dilakukan oleh 4 orang validator yaitu 3 orang dosen kimia dan 1 orang guru kimia.

\section{1) Validasi Ahli Terhadap Media Pembelajaran}

Kriteria yang digunakan untuk menyatakan bahwa media pembelajaran memenuhi kriteria validitas yang baik adalah apabila rata-rata penilaian ahli untuk setiap aspek berada dalam kriteria minimal valid dengan nilai persentase 6984\%. Hasil penilaian ahli terhadap media pembelajaran Tera-tera disajikan dalam lampiran 7 dan analisisnya diringkas pada Tabel 1 .

Tabel 1. Hasil Analisis Validitas Media Pembelajaran

\begin{tabular}{ccccccccc}
\hline \multirow{2}{*}{ No. } & Aspek Yang & \multicolumn{9}{c}{ Skor Penilaian Validator } & \multirow{2}{\text{Skor}}{$\begin{array}{c}\text { \% Skor } \\
\text { Rata-rata } \\
\text { Rata-rata }\end{array}$} & $\begin{array}{c}\text { Kategori } \\
\text { Validitas }\end{array}$ \\
\cline { 3 - 6 } & Dinilai & $\mathbf{1}$ & $\mathbf{2}$ & $\mathbf{3}$ & $\mathbf{4}$ & 4,00 & \\
1 & Perwajahan & 5.00 & 4,25 & 4,00 & 4,75 & 4,50 & 90,00 & SV \\
2 & Kelayakan Isi & 5,00 & 4,60 & 4,00 & 4,60 & 4,55 & 91,00 & SV \\
3 & Kontruksi & 5,00 & 4,40 & 3,80 & 4,60 & 4,45 & 89,00 & SV \\
4 & Kelayakan Bahasa & 5,00 & 4,33 & 3,67 & 5,00 & 4,50 & 90,00 & SV \\
& Rata-rata & $\mathbf{5 , 0 0}$ & $\mathbf{4 , 4 0}$ & $\mathbf{3 , 8 7}$ & $\mathbf{4 , 7 4}$ & $\mathbf{4 , 5 0}$ & $\mathbf{9 0 , 0 0}$ & SV \\
\hline
\end{tabular}

Berdasarkan Tabel 1 penilaian ahli terhadap media pembelajaran, maka keseluruhan media pembelajaran memiliki persentase skor rata-rata 90.00\% dengan kategori sangat valid (SV) sehingga layak digunakan dalam pembelajaran.

\section{2) Validasi Ahli Terhadap Rencana \\ Pelaksanaan Pembelajaran (RPP)}

Kriteria yang digunakan untuk menyatakan bahwa RPP memenuhi kriteria validitas yang baik adalah apabila rata-rata penilaian ahli untuk setiap aspek berada dalam kriteria minimal valid dengan nilai persentase $69-84 \%$. Hasil penilaian ahli terhadap RPP disajikan dalam lampiran 8 dan analisisnya diringkas pada Tabel 2.

Tabel 2. Hasil Analisis Validitas RPP

\begin{tabular}{|c|c|c|c|c|c|c|c|c|}
\hline \multirow{2}{*}{ No. } & \multirow{2}{*}{ Aspek Yang Dinilai } & \multicolumn{4}{|c|}{ Skor Penilaian Validator } & \multirow{2}{*}{$\begin{array}{c}\text { Skor } \\
\text { Rata-rata }\end{array}$} & \multirow{2}{*}{$\begin{array}{c}\text { \% Skor } \\
\text { Rata-rata }\end{array}$} & \multirow{2}{*}{$\begin{array}{l}\text { Kategori } \\
\text { Validitas }\end{array}$} \\
\hline & & 1 & 2 & 3 & 4 & & & \\
\hline 1 & $\begin{array}{c}\text { Perumusan Tujuan } \\
\text { Pembelajaran }\end{array}$ & 4,80 & 3,60 & 4,00 & 4,40 & 4,20 & 84,00 & V \\
\hline 2 & Isi Yang Disajikan & 4,40 & 4,00 & 4,00 & 4,00 & 4,10 & 82,00 & $\mathrm{~V}$ \\
\hline 3 & Bahasa & 5,00 & 5,00 & 4,00 & 5,00 & 4,75 & 95,00 & SV \\
\hline \multirow[t]{2}{*}{4} & Waktu & 5,00 & 5,00 & 4,00 & 4,00 & 4,50 & 90,00 & SV \\
\hline & Rata-rata & $\mathbf{4 , 8 0}$ & $\mathbf{4 , 4 0}$ & 4,00 & 4.35 & 4.39 & 87,75 & SV \\
\hline
\end{tabular}

Berdasarkan Tabel 2 penilaian ahli terhadap RPP, maka keseluruhan RPP memiliki persentase skor rata-rata $87,75 \%$ dengan kategori sangat valid
(SV) sehingga layak digunakan dalam pembelajaran. 


\section{3) Validasi Ahli Terhadap Lembar Kerja Peserta Didik (LKPD)}

Kriteria yang digunakan untuk menyatakan bahwa LKPD memenuhi kriteria validitas yang baik adalah apabila rata-rata penilaian ahli untuk setiap aspek berada dalam kriteria minimal valid dengan nilai persentase $69-84 \%$. Hasil penilaian ahli terhadap LKPD disajikan dalam lampiran 9 dan analisisnya diringkas pada Tabel 3.

Tabel 3. Hasil Analisis Validitas LKPD

\begin{tabular}{|c|c|c|c|c|c|c|c|c|}
\hline \multirow{2}{*}{ No. } & \multirow{2}{*}{$\begin{array}{c}\text { Aspek Yang } \\
\text { Dinilai }\end{array}$} & \multicolumn{4}{|c|}{ Skor Penilaian Validator } & \multirow{2}{*}{$\begin{array}{c}\text { Skor } \\
\text { Rata-rata }\end{array}$} & \multirow{2}{*}{$\begin{array}{c}\% \text { Skor } \\
\text { Rata-rata }\end{array}$} & \multirow{2}{*}{$\begin{array}{l}\text { Kategori } \\
\text { Validitas }\end{array}$} \\
\hline & & 1 & 2 & 3 & 4 & & & \\
\hline 1 & Isi Yang Disajikan & 5,00 & 4,50 & 4,00 & 4,00 & 4,38 & 87,50 & SV \\
\hline \multirow[t]{2}{*}{2} & Bahasa & 5,00 & 4,60 & 4,00 & 4,80 & 4,60 & 92,00 & SV \\
\hline & Rata-rata & 5,00 & 4,55 & 4,00 & $\mathbf{4 , 4 0}$ & 4,49 & 89,75 & SV \\
\hline
\end{tabular}

Berdasarkan tabel 3 penilaian ahli terhadap LKPD, maka keseluruhan LKPD memiliki presentase skor rata-rata $89,75 \%$ dengan kategori sangat layak (SL) sehingga layak digunakan dalam pembelajaran.

\section{c. Revisi Produk}

Setelah proses validasi oleh tim validator ahli, kemudian peneliti melakukan revisi produk yang mengacu pada masukan dan saran dari tim validator terhadap produk yang dikembangkan agar menarik dan sesuai dengan kebutuhan peserta didik. Produk media pembelajaran permainan tera-tera dapat dilihat pada Gambar 1.

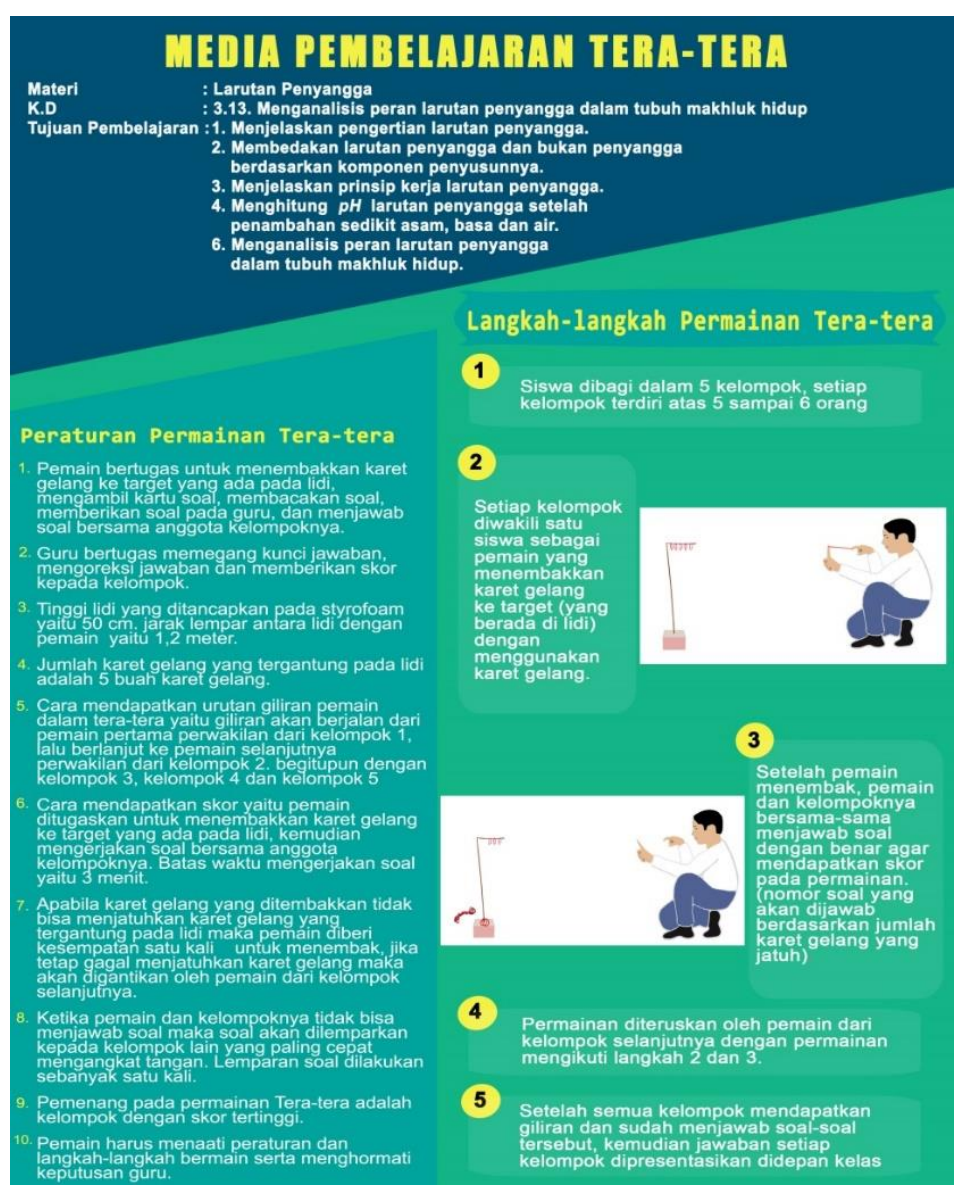

Gambar 1. Produk Permainan Tera-tera 1) Identitas, 2) Peraturan permainan Tera-tera, 3) Langkahlangkah permainan Tera-tera.

Gambar diatas merupakan produk desain media pembelajaran dalam bentuk sketsa langkah- 
langkah permainan tera-tera yang telah divalidasi oleh validator ahli media, validator ahli materi dan telah direvisi

\section{KESIMPULAN}

Berdasarkan hasil penelitian dan pembahasan media pembelajaran Tera-tera materi larutan penyangga, dapat disimpulkan bahwa media pembelajaran Tera-tera pada materi larutan penyangga telah valid berdasarkan penilaian dari empat validator diperoleh rata-rata skor keseluruhan untuk media pembelajaran sebesar 90,00\%, RPP sebesar 87,75\%, dan LKPD sebesar 89,75\% dengan kategori sangat valid (SV).

Berdasarkan hasil penelitian yang dilakukan, saran yang dapat diberikan kepada peneliti lainnya untuk dapat melanjutkan penelitian pengembangan media pembelajaran ini sampai pada tahap implementasi (implementation) hingga tahap evaluasi (evaluation), karena penelitian pengembangan media pembelajaran ini dilakukan hanya sampai tahap validasi dan revisi produk ditahap pengembangan (development).

\section{UCAPAN TERIMA KASIH}

Terima kasih yang begitu besar kepada Bapak Hendri Iyabu, S.Pd, M.Si selaku pembimbing I sekaligus penasehat akademik, Bapak Suleman Duengo, S.Pd, M.Si selaku pembimbing II yang telah meluangkan waktu dengan tulus, ikhlas membimbing dan membantu serta memberi saran dan dorongan sehingga penulis dapat menyelesaikan skripsi ini.

\section{DAFTAR PUSTAKA}

Argandi, R., \& Martini, K. S. (2013). Pembelajaran Kimia Dengan Metode Inquiry Real dan Virtual Pada Pokok Bahasan Pemisahan Campuran. Pendidikan Kimia, 2(2), 44-49.

Asra, S. (2016). Metode Pembelajaran. Bandung: CV Wacana Prima.
Ervianna, R., Sari, K., Hadi, D. S., Si, M., Prishardoyo, D. B., \& Si, M. (2012). Upaya Peningkatan Hasil Belajar Dengan Menggunakan Model Pembelajaran Kooperatif Team Games Tournament. Economic Education Analysis Journal, 1(1).

Heriyanto, A., Haryani, S., \& Sedyawati, S. (2014). Pengembangan Multimedia Pembelajaran Interaktif Berbasis Education Game Sebagai Media Pembelajaran Kimia. Chemistry in Education, 3(1).

Kusumawardani, A., Utami, B., \& Sukardjo, J. (2015). Penerapan Metode Numbered Heads Together (NHT) Dilengkapi Lingkaran Buffer Untuk Meningkatkan Motivasi Dan Prestasi Belajar Siswa Pada Materi Larutan Penyangga Kelas XI IPA 4 SMAN 2 Karanganyar Tahun Pelajaran 2012/2013. Pendidikan Kimia, 4(4), 207-216.

Novianty, Akhyar, O., \& Mashuri, M. T. (2018). Pengaruh Media Dart Board Terhadap Minat Belajar Kimia Siswa Pada Materi Koloid Di Kelas XI SMA Negeri 12 Banjarmasin. Pendidikan Kimia, 1(2).

Ratumanan, T. G., dan Laurens T. (2003). Evaluasi Hasil Belajar. Surabaya: Unesa University Press.

Rengen, Y. E., Sahputra, R., \& Rasmawan, R. (2017). Pengaruh Model TGT Berbantuan Media TTS Terhadap Hasil Belajar Siswa Pada Materi Tata Nama Senyawa. Pendidikan Dan Pembelajaran, 7(1).

Ristiyani, E., \& Bahriah, E. S. (2016). Analisis Kesulitan Belajar Kimia Siswa Di SMAN X Kota Tangerang Selatan. Penelitian Dan Pembelajaran IPA, 2(1), 18-29.

Sugiyono. (2019). Metode Penelitian Kuantitatif, Kualitatif dan $R \& D$. Bandung: Alfabeta.

Taniredja, T., Faridli, E. M., \& Harmiyanto, S. (2012). Model-model Pembelajaran Inovatif. Bandung: Alfabeta. 